Published in final edited form as:

Semin Ophthalmol. 2013 ; 28(0): 287-300. doi:10.3109/08820538.2013.825297.

\title{
Gene Therapy in Corneal Transplantation
}

\author{
Yureeda Qazi ${ }^{1}$ and Pedram Hamrah ${ }^{1,2}$ \\ ${ }^{1}$ Cornea and Refractive Surgery Service, Department of Ophthalmology, Massachusetts Eye and \\ Ear Infirmary, Harvard Medical School, Boston, MA, USA \\ ${ }^{2}$ Schepens Eye Research Institute, Massachusetts Eye and Ear, Department of Ophthalmology, \\ Harvard Medical School, Boston, MA, USA
}

\begin{abstract}
Corneal transplantation is the most commonly performed organ transplantation. Immune privilege of the cornea is widely recognized, partly because of the relatively favorable outcome of corneal grafts. The first-time recipient of corneal allografts in an avascular, low-risk setting can expect a $90 \%$ success rate without systemic immunosuppressive agents and histocompatibility matching. However, immunologic rejection remains the major cause of graft failure, particularly in patients with a high risk for rejection. Corticosteroids remain the first-line therapy for the prevention and treatment of immune rejection. However, current pharmacological measures are limited in their side-effect profiles, repeated application, lack of targeted response, and short duration of action. Experimental ocular gene therapy may thus present new horizons in immunomodulation. From efficient viral vectors to sustainable alternative splicing, we discuss the progress of gene therapy in promoting graft survival and postulate further avenues for gene-mediated prevention of allogeneic graft rejection.
\end{abstract}

\section{Keywords}

Alternative splicing; angiogenesis; graft survival; immunomodulation; keratoplasty; nanotechnology

\section{INTRODUCTION}

Corneal transplantation is the most commonly performed organ transplantation in the United States, with an estimated 46,196 cases performed annually. ${ }^{1}$ Even though corneal allografts enjoy the privilege of being among the most successful solid organ transplants, their twoyear graft survival rate of over $90 \%$ in "low-risk" avascular host beds significantly decreases over time. ${ }^{2-5}$ Nevertheless, immunologic rejection remains a leading cause of graft failure.

The prevalence of graft rejection varies from 5\% to 40\%, depending upon vascularization of the recipient cornea and prior episodes of graft failure, ${ }^{6-8}$ with rejection rates approaching $70 \%$ in vascularized "high-risk" beds, even with maximal local and systemic immune suppression. ${ }^{9}$ Therefore, the aims in management of immune-mediated graft rejection are two-fold: first, to inhibit or regress corneal neovascularization that is usually accompanied by the ingrowth of lymph vessels, ${ }^{10-14}$ and second, to prevent or reverse immune-mediated

(C) Informa Healthcare USA, Inc.

Correspondence: Pedram Hamrah, M.D., Massachusetts Eye and Ear Infirmary, Department of Ophthalmology, Harvard Medical School, 243 Charles Street, Boston, MA 02114, USA. pedram_hamrah@meei.harvard.edu.

DECLARATION OF INTEREST

The authors report no conflicts of interest. The authors alone are responsible for the content and writing of the paper. 
graft rejection. The complex construct of corneal immune-mediated graft rejection defined by interplay of angiogenesis, lymphangiogenesis, inflammation, and loss of immune privilege, necessitates polytherapy targeting both inflammation and angiogenesis (heme and lymph) to provide for the best visual outcomes. ${ }^{11,15,16}$ Nevertheless, pharmacotherapy is plagued by short duration of action, adverse effects such as glaucoma, cataracts, and opportunistic infections, frequent application, as well as immunogenicity of small molecule biologic therapy.

Gene therapy is a molecular beacon of hope for diseases once considered incurable. Viral vectors such as recombinant adeno-associated virus-2 (AAV-2) have met with prolific success in retinal gene therapy, and have therefore made their way to clinical trials. Currently, there are 28 active ocular gene therapy clinical trials in progress worldwide, ${ }^{17}$ covering conditions such as retinal degenerations, age-related macular degeneration, glaucoma, and corneal scarring. ${ }^{17,18}$ However, gene therapy for anterior segment disease is still evolving, and under heavy investigation. Nevertheless, orthotopic corneal transplantation presents a unique platform providing ease of vector delivery to both the donor graft ex vivo, and the recipient bed in vivo, prior to transplantation. ${ }^{19-22}$ In our review, we discuss the viral and nonviral vectors available for corneal drug and gene delivery, the current success of preclinical gene therapy in promoting allogeneic corneal graft survival, and potential implications for the future management of graft rejection.

\section{MATERIALS AND METHODS}

All references included in our review were collated through PubMed using the keywords "cornea gene therapy," "corneal graft rejection," "corneal transplantation," "corneal graft survival gene therapy," "cornea graft survival," "cornea graft survival genetic modulation," and "genetic modulation immune tolerance." Bibliography of the selected publications was also reviewed for inclusion in our manuscript.

\section{RESULTS}

\section{Pathophysiology of Corneal Graft Rejection}

Understanding the molecular and cellular underpinnings of ocular immune privilege is imperative to formulating effective, cell-specific and targeted therapies to restore immune homeostasis, promote graft survival, and provide optical clarity. Corneal immune privilege is evident from the high survival rates of allogeneic corneal grafts despite the lack of human leukocyte antigen (HLA) matching between donor tissues and recipients of grafts. The unique corneal anatomy and physiology of the anterior chamber allows for low immunogenicity and maintenance of alloantigen tolerance. ${ }^{23-25}$ The cornea is a uniquely avascular tissue and free of lymphatic vessels, preventing unrestricted access of antigens and antigen-presenting cells (APCs) to T-cell-rich secondary lymphoid organs. Constitutive expression of major histocompatibility complex (MHC)-I and -II antigens is low or absent in all layers of the central cornea, further limiting immunogenicity to foreign antigens. Corneal dendritic cells (DCs) are among the most potent APCs, but exist in a quiescent state in a healthy cornea, ${ }^{26-28}$ responsible for immune surveillance. The cornea expresses many cell-membrane-bound molecules that protect it from immune-mediated inflammation and induce apoptosis of deleterious effector T cells. The repertoire of these molecules includes complement regulatory proteins (CRP), Fas ligand (FasL), MHC-Ib, and tumor necrosis factor (TNF)-related apoptosis-inducing ligand (TRAIL). FasL (CD95L), a pro-apoptotic molecule, is expressed by the corneal epithelium and endothelium. FasL serves to destroy neutrophils and effector T cells that express its receptor Fas/CD95, placing measures against immune-mediated graft rejection. ${ }^{29,30}$ In addition, the corneal epithelium, stroma, and cells of the ciliary body also express programmed death ligand-1 (PDL-1), which upon interaction 
with its cognate receptor (PD-1) on T cells leads to arrest of $\mathrm{T}$ cell proliferative capacity, induction of apoptosis, and suppression of interferon (IFN)- $\gamma$ secretion, ${ }^{31}$ improving corneal graft survival. ${ }^{32,33}$ PD-1 inhibits T cell proliferation by suppressing Ras and Akt signaling pathways, which in turn inhibit transcription of SKP2, thus leading to up-regulation of transforming growth factor (TGF)- $\beta$-specific transcription factor Smad3, resulting in cell cycle arrest. ${ }^{34}$

The anterior chamber is laden with soluble inhibitory factors such as TGF- $\beta$, alphamelanocyte stimulating hormone (a-MSH), calcitonin gene-related peptide (CGRP), CRP, somatostatin (SOM), indoleamine dioxygenase (IDO), vasointestinal peptide (VIP), and macrophage migration inhibitory factor (MIF) that, in part, suppress $\mathrm{T}$ cell and complement activation. ${ }^{23,35}$ Moreover, anterior chamber-associated immune deviation (ACAID), an alloantigen-specific peripheral immune tolerance to antigens in the anterior chamber, is capable of suppressing the systemic cytotoxic immune response. ${ }^{36-39}$ ACAID has been shown to promote corneal graft survival by suppressing delayed-type hypersensitivity (DTH) responses and by maintaining humoral immunity. ${ }^{40,41}$ The cornea provides a niche for dendritic cells (DCs), which are key players in the modulation of corneal immunogenicity. ${ }^{42}$ Resident central corneal DCs are MHC-II negative, but with a change in the molecular milieu of the cornea from a quiescent to an inflammatory state, as in corneal transplantation, they may express MHC-II molecules. ${ }^{26,27,43,44}$ The importance of corneal APCs in graft rejection is underscored by the fact that corneal graft rejection is largely a consequence of allorecognition. ${ }^{42,45}$

Graft rejection is an immune-mediated process that can target specific layers of the cornea, including the corneal endothelium. The corneal endothelium has limited proliferative ability, which when undergoing apoptosis during graft rejection can lead to inevitable graft failure ${ }^{46}$ Sensitization of the host to donor antigens forms the "afferent" arm of corneal allograft rejection process and is induced by corneal APCs. ${ }^{26,27,43,44}$ Corneal DCs play a critical role in graft rejection through their ability to regulate T-cell responses to both self and foreign antigens in the donor button, based on molecular cues received from the tissue microenvironment. ${ }^{28}$ Antigen recognition and capture occur through major histocompatibility class-II antigens on the surface of mature DCs. Once APCs arrive in draining lymph nodes, they can sensitize $\mathrm{T}$ cells and induce their proliferation.

T cell sensitization occurs when APCs present donor antigens to naïve T-cells. ${ }^{47,48}$ Donor antigens may be presented in a direct or indirect fashion, based on whether they are presented to T cells directly by donor APCs, or, indirectly by host APCs after uptake and processing of donor antigens. ${ }^{48-50}$ The direct pathway involves presentation of donor antigens to T cells directly by donor APCs through non-self MHC-II recognition on their surface, leading to the production of direct alloreactive T cells. ${ }^{24}$ In contrast, in the indirect pathway, donor antigens are first presented to host corneal APCs that arrive at the cornea, capture donor antigens, and transport them to the lymph nodes for antigen presentation to naïve T cells through MHC-II expressed on APCs. ${ }^{24}$ Both the direct and indirect pathways are implicated in the immune-mediated rejection of orthotopic corneal allografts, especially in "high-risk" corneal beds, ${ }^{49-53}$ with the indirect pathway being implicated in the "lowrisk" setting. ${ }^{54}$

The "efferent" arm, or the expression phase, of the rejection process refers to the actual destruction of the graft by effector $\mathrm{T}$ cells. Following sensitization, activation, and proliferation of naïve $\mathrm{T}$ cells, trafficking of alloreactive effector $\mathrm{T}$ cells to the cornea is mediated by a multi-step adhesion cascade that includes chemokines, which take part in the recruitment of leukocytes to the inflamed cornea. Immune-mediated damage to the graft begins with the release of cytokines, such as TNF-a and interleukin (IL)-1, secondary to the 
mechanical trauma of surgery. In high-risk corneal transplantation, these cytokines induce the production of chemokines such as MCP-1, regulated on activation normal T cell expressed and secreted (RANTES), macrophage inflammatory protein (MIP)-1a and MIP-1 $\beta$ in leading to recruitment of APCs and T cells into the cornea. ${ }^{23,55-57}$ In the cornea, these alloreactive $\mathrm{T}$ cells recognize donor MHC antigens, and induce the development of memory $\mathrm{T}$ cells. ${ }^{24}$ Graft rejection is orchestrated mainly by $\mathrm{CD} 4{ }^{+} \mathrm{T}$-helper (Th) cells and by $\mathrm{CD} 8^{+}$cytotoxic T cells. ${ }^{58,59,24,60} \mathrm{CD} 4^{+}$Th1 cells secrete IL-2, IFN- $\gamma$, and lymphotoxin. IL-2 sustains the immune response by a positive feedback on $\mathrm{T}$ and $\mathrm{B}$ cell activation and proliferation, while IFN- $\gamma$ ensures that macrophages are activated at the site of inflammation, and facilitates further expression of MHC-II antigens in the donor button.

\section{Current Methods to Prolong Corneal Graft Survival}

Traditional measures in the management of graft rejection employ immunosuppression primarily through the use of topical and systemic corticosteroids, either as monotherpy or in combination with other immunosuppressive agents. ${ }^{61-63}$ The caveat to corticosteroid therapy is its aggressive side-effect profile, ranging from increased intraocular pressure, cataract formation, impaired wound healing, and predisposition to opportunistic infections, necessitating careful monitoring. Corneal neovascularization, which has been associated with increased rejection, may be additionally addressed by either the use of mechanical measures such as cautery and diathermy, which in itself are not practical nor provide sustained control, or the more efficacious delivery of topical or subconjunctival bevacizumab, a humanized anti-VEGF monoclonal antibody, which has proved successful in the inhibition and partial regression of neovessels, albeit short-lived. ${ }^{64-70}$

Other measures to curtail immune-mediated graft rejection employ pharmacological interference of $\mathrm{T}$ cell activation and proliferation, targeting $\mathrm{T}$ cell receptors, and modulating effector T cell responses. Calcineurin inhibitors, such as cyclosporine A (CsA) and tacrolimus (FK506), have proven efficacious to varying degrees in the treatment of graft rejection and management of high-risk grafts. ${ }^{71-74}$ They provide for alternative or additional measures in lieu of corticosteroids for chronic immune suppression. Topical CsA (2\%) provides effective maintenance of graft clarity in adult and pediatric patients. ${ }^{75-78}$ Combination therapy of topical CsA with topical steroids has yielded controversial and mixed results. While some randomized clinical trials demonstrate no further benefit in the treatment of acute endothelial graft rejection, ${ }^{79}$ other case-control studies report a clear advantage to graft survival in the management of post-transplant rejection prophylaxis. ${ }^{77,61,78,80}$ Furthermore, randomized controlled trials have demonstrated that mycophenolate mofetil (MMF), an inhibitor of inosine monophosphate dehydrogenase (IMPDH), is superior to topical CsA in preventing graft rejection episodes in high-risk patients $, 81,82$ which can also be combined with steroids in the management of high-risk cases. ${ }^{61}$ Rapamycin (sirolimus) retards $\mathrm{T}$ cell proliferation and activation without affecting regulatory $\mathrm{T}$ cells. Rapamycin has been shown to be comparable in its efficacy to MMF in the management of high-risk grafts, ${ }^{83}$ and can be used in combination to manage such patients, ${ }^{84}$ but with discretion given their additive systemic toxicity.

Targeting $\mathrm{T}$ cell antigens through intracameral delivery of monoclonal antibodies to CD3 and CD6 has successfully treated episodes of acute graft rejection. ${ }^{85,86}$ Monoclonal antibodies to $\mathrm{T}$ cell receptors such as IL-2R inhibit T cell proliferation. These monoclonal antibodies may be combined with immunosuppressives such as CsA in the management of high-risk transplant patients. ${ }^{87}$ While they are less effective than CsA in preventing and treating graft rejection episodes in high-risk grafts, anti-IL2R antibodies appear to have minimal side-effects. ${ }^{88}$ 
As illustrated above, current measures to promote and maintain graft survival and tackle acute graft rejection remain limited in their scope and utility given the adverse effects associated with their use, need for repeated application, short duration of action, and widespread systemic toxicity.

\section{Vectors in Corneal Gene Therapy}

The cornerstone of a promising gene-based therapeutic approach lies much in the way of the vector used to carry the deliverable, as is the route taken to deliver the vector. Successfully integrating DNA into cells of interest and ensuring localized, continued gene expression without evoking an immune response or inducing systemic pathogenicity is critical to the vector's translational success. Even though the cornea is an immune privileged site creating an ideal environment for the introduction of foreign DNA and protein, ${ }^{89,90}$ the introduced vector should be minimally immunogenic to offset an avid immune response in the setting of active inflammation such as acute graft rejection. Thus, the eventual utility of a vector lies in its capacity to efficiently transfect cells of interest, ${ }^{21,91,92}$ maintain sustained gene expression, ${ }^{21}$ and induce minimal immunogenicity without any off-target and systemic adverse effects. ${ }^{92,93}$ While first- and second-generation adenoviral vectors were highly efficient at transfecting cells and inducing gene expression, they were immunogenic and also induced non-specific cell transfection, making them undesirable candidates. Likewise, certain serotypes of AAVs have poor transduction into cells despite their low immunogenicity ${ }^{94,95}$ Viral and non-viral vectors may be delivered to the cornea by a number of physical and chemical methods. Among the tested routes of gene delivery to the cornea, successful modes have been topical, intrastromal, intracameral, intravitreal, subconjunctival, ballistic transfer, laser and dehydration of the corneal surface.

\section{Viral Vectors}

Adenovirus-Adenoviruses (Ad) are a family of double-stranded DNA viruses that cause mild respiratory tract infection in humans. ${ }^{96}$ They enter cells by receptor-mediated endocytosis through coxsackie-adenovirus receptor (CAR) binding and interaction with $\alpha_{v} \beta_{3}$ integrins, leading to its internalization. ${ }^{97-100}$ The viral genome is released by endosomal lysis, after which it travels to the nucleus where it replicates episomally without integrating into the host genome. Recombinant adenoviruses have been tested extensively as vectors for corneal gene delivery to both the corneal epithelium and endothelium. ${ }^{101-104}$ While recombinant Ad5 is less immunogenic than the first- and second-generation constructs, gene expression in ocular tissue has been inconsistent across species (rat, rabbit, mouse, sheep) ${ }^{105-107}$ and variable depending upon experimental conditions (in vitro, ex vivo, in vivo). ${ }^{106,108}$ Ad5 demonstrates efficiency in transfecting corneal endothelial cells ${ }^{105,107,109}$ and stromal keratocytes, ${ }^{22}$ but the corneal epithelium poses resistance to transfection in vivo, ${ }^{106}$ making Ad5 more suited to delivering genes to the corneal epithelium ex vivo. ${ }^{110}$ Even though introduction of the Ad5 vector into the conjunctiva ex vivo has been shown to induce inflammation by up-regulation of cytokines such as IL-6 and IL-8, and adhesion molecules such as intercellular adhesion molecule (ICAM)-1, ${ }^{106}$ this has not affected the success of ex-vivo Ad5-transfected orthotopic corneal allografts. ${ }^{105}$ Hence, the advantages of this vector are its lack of insertional mutagenesis, ability to transfect both mitotic and amitotic cells, and a capacity for large DNA inserts. The caveat to using Ad vectors is a short duration of gene expression due to an immune response against viral antigens expressed by transfected cells. This stems from memory to the antigens in humans through prior exposure to adenoviral respiratory tract infections.

Adeno-Associated Virus-Adeno-associated viruses (AAV) belong to the family of parvoviridae. They are naked, single-stranded DNA viruses. AAVs require co-infection with a helper virus in order to replicate successfully owing to the simplicity of their own 
genome. ${ }^{111}$ The AAV genome has two open-reading frames, rep and cap. Rep proteins are responsible for viral replication, transcription, packaging of viral genome, and insertion into host genome, whereas cap genes code for the viral capsid. ${ }^{111,112}$ Recombinant adenoassociated virsuses (rAAVs) replace rep and cap genes with therapeutic genes that later integrate into the host genome to provide sustained, long-term gene expression, making them the most coveted viral vectors. Therefore, rAAVs require co-infection with AAV helper plasmids that express rep and cap genes, and an additional E1-deleted adenovirus helper plasmid. It is now possible to incorporate both the AAV-helper and adenovirus-helper genes into a single plasmid to allow adenovirus-free co-infection. ${ }^{113}$ Of the eight different serotypes, AAV2 is the most widely used serotype for gene therapy studies. ${ }^{114}$ However, certain cells such as vascular endothelial cells are resistant to transfection with AAV2. ${ }^{94,95}$ Even though AAV2 is able to infect a wide array of cells through binding with cell surface heparan sulfate proteoglycans (HSPG) as its primary binding receptor, cellular tropism is much wider with AAV5, since it binds to all cells that express 2,3-linked sialic acid, and is therefore able to transfect vascular endothelial cells as seen in its successful gene transfer to the retina. ${ }^{115-117}$ Of these two serotypes, AAV5 is more efficient at transfecting corneal stromal cells. ${ }^{118}$ rAAVs in corneal gene delivery have been shown to successfully transfect the cornea ex vivo and in vivo without observable toxic effects, delivering genes of interest to the endothelium and stromal keratocytes. ${ }^{119-121}$ Newer serotypes, such as AAV-6,-8 and -9 , postulated in earlier years to be less immunogenic given their extraction from Rhesus monkeys, and providing more robust sustained gene expression, ${ }^{122}$ have now been confirmed through recent studies in mouse and man. ${ }^{21,123}$ A single stromal injection of AAV2/8 delivered in vivo in mice and ex vivo in humans sustained targeted gene expression in keratocytes for up to 17 months in mice, and until the end of the eight-week experimental period in humans, without any toxic side-effects in either species, making AAV8 a strong candidate for stromal gene therapy. ${ }^{21}$ In vitro studies on human corneal fibro-blasts further bolster the impressive transduction efficacy of AAV6, -8 , and -9 in delivering and sustaining gene expression with an exceptional cellular viability of $97 \%$, making them potentially safe for clinical use. ${ }^{123}$

Among the viral vectors, AAVs therefore boast the safest profile for clinical use. rAAVs exhibit high transduction efficiency by transducing both mitotic and amitotic cells, and a quick yet sustained gene expression through integration into the host genome with low immunogenicity, making them excellent vectors for clinical use. A major drawback of AAVs is their inability to incorporate large DNA constructs. This issue, however, has been addressed through concatomerization of their genome. ${ }^{124,125}$ Ground-breaking progress has been made to reduce loading titers and increase transduction efficiency of AAV vectors through surface functionalization by creating tyrosine mutant AAV vectors (AAV2, AAV8, and AAV9) that prevents ubiquitination and proteasomal degradation of AAV. ${ }^{126-129}$. Their effective delivery to murine corneal endothelium in vivo has also been demonstrated, ${ }^{130}$ creating much anticipation of their translational capability.

Lentivirus-Lentiviruses belong to the Retroviridae family of single-stranded enveloped RNA viruses. Their genome bear $g a g$, pol, and env genes along with other open reading frames (ORFs) that can be used for insertion of genes of therapeutic interest. ${ }^{131,132}$ Of the family of lentiviridae, human immunodeficiency virus (HIV)-1 has the largest number of ORFs and has been most heavily investigated. ${ }^{132}$ Lentiviridae differ from other retroviridae in their ability to transduce amitotic cells as well, but like all retroviridae, they possess the enzyme reverse transcriptase that transcribes its RNA into double-stranded DNA upon entry of the virus into a cell. ${ }^{133}$ Lentiviridae demonstrate an inherent tropism for macrophages and $\mathrm{CD}^{+}$cells. ${ }^{134,135}$ However, genetic engineering of HIV-1 has eliminated this cell-specific limitation through replacement of the HIV env protein with a $G$ protein from vesicular stomatitis virus (VSV), allowing transfection of a larger population of cells. HIV-based 
lentivirus vectors now typically comprise a transfer vector that comprises a CMV promoter, rev responsive element (RRE), and a packaging signal. Two helper plasmids are also incorporated, one of which provides rev in a trans form, while the other provides gag, pol, and VSV G protein. ${ }^{118,130}$ These modifications enable minimal retention of the HIV viral genome, minimizing the risk of the formation of recombination-mediated replicationcompetent strains while retaining the virus's ability to replicate, along with modifications made to diversify the transduced cell population. New-generation lentivirus vectors are thus safer candidates for gene therapy.

There are several advantages to using lentivirus vectors for corneal gene therapy: first, they can sustain prolonged gene expression; second, they can transduce many different types of cells, including amitotic cells; third, lentiviral vectors lead to rapid protein expression, while maintaining cell viability. Nevertheless, even the slightest possibility of recombinationmediated replication-competent strains being generated through integration of the virus into the human genome remains too great a risk to take towards testing of such vectors in clinical trials.

Albeit in experimental investigation to date, lentiviral vectors can successfully transduce corneal epithelial (human; ex vivo), ${ }^{136}$ stromal (murine and bovine; in vivo) ${ }^{118}$ and endothelial (mouse; in vivo) ${ }^{137,138}$ cells using various techniques such as intracameral, intravitreal. and intrastromal injections of the virus. Furthermore, lentiviral vectors have been successfully used to deliver genes of interest towards prolonging corneal allograft survival. ${ }^{19,139-141}$

\section{Non-Viral Vectors}

Nanoparticles-Nanotechnology is a leap towards biodegradable, non-immunogenic, and sustainable gene delivery to the anterior and posterior segments of the eye. ${ }^{142-145}$ Unlike viral vectors that evoke an immune response, or naked plasmids that are unable to provide sustained effects, nanocarriers bridge the gap between effective gene targeting and a sustained gene expression without overt activation of the immune system. ${ }^{93,142,146-148}$ Nanopolymers are biodegradable and may be engineered to deliver proteins, drugs, and plasmids with slow-release kinetics and greater permeability, producing sustained effects. ${ }^{149,150}$ Nanoparticles (NPs) containing compacted DNA are superior to AAV, the established viral vector for ocular gene therapy, in that they have a larger vector-carrying capacity enabling delivery of genes too large for the AAV vector, while exhibiting comparable gene expression efficiency and sustainable gene and protein expression profiles. ${ }^{144,151,152}$ Surface functionalization of nanoparticles makes them a particularly attractive candidate for transgene delivery, enabling targeted therapy while preventing offtarget effects. ${ }^{153-155}$

Dendrimers-Starburst polyamidoamine (PAMAM) dendrimers are a class of synthetic polymers that form dendrimer-DNA complexes, which efficiently transfect a wide variety of mammalian cells to induce sustainable gene expression with minimal cytotoxicity and immunogenicity. ${ }^{156,157}$ Ex vivo studies have demonstrated the ability of activated PAMAM dendrimers to successfully transduce corneal endothelial cells. One such study demonstrated the efficacy of PAMAM dendrimers complexed with plasmids expressing the gene for tumor necrosis factor receptor protein (TNFR-Ig) in the ex-vivo transfection of human and rabbit corneas to induce gene and protein expression. ${ }^{158}$ Quarter corneas were incubated for three hours with dendrimer-DNA complexes containing $2 \mathrm{gg}$ of plasmid and $36 \mathrm{gg}$ of dendrimers (1:18 ratio of plasmid:dendrimer). In both rabbit and human whole-thickness corneas, only the endothelial cells were transfected with secreted TNFR-Ig in the 
supernatant, ${ }^{158}$ presenting yet another non-viral platform for the genetic modulation of corneal endothelial graft rejection.

\section{Gene Therapy in Corneal Graft Survival}

Anti-Angiogenesis-Vascularized corneal beds pose a high risk for corneal graft rejection. Corneal vascularity is followed closely by the growth of lymphatic vessels, both of which inundate the immune-privileged cornea with inflammatory cells, activated APCs, and $\mathrm{T}$ cells that release cytokines and chemokines, leading to destruction of the corneal bed and further amplification of the immune response, culminating in graft rejection. Therefore, methods for inhibition and regression of blood and lymph vessels are a focal strategy to maintaining graft clarity and survival. Such strategies have been tested through murine studies employing gene transfer techniques, either treating the donor button ex vivo, or the host graft bed in vivo. In the setting of inflammatory neovascularization of the recipient corneal bed, knocking down neuropilin-2 (NP2) in the recipient tissue prior to transplantation using ribonucleic acid interference (RNAi) significantly improved graft survival rate by selectively decreasing lymphangiogenesis, thereby emphasizing the importance of lymphangiogenesis in the pathophysiology of graft failure. ${ }^{159}$ Murine studies have elegantly demonstrated that poly-lactic co-glycolic acid nanoparticle (PLGA NP)mediated targeting of Flt23k, an intraceptor of VEGF-A, improves graft survival by $20 \%$ through inhibition of heme- and lymph-angiogenesis. ${ }^{160}$ Addition of triamcinolone, a corticosteroid, yielded prolonged graft survival by $90 \%$, reconfirming that graft survival is best achieved by inhibiting a multitude of pathological processes inclusive of angiogenesis, inflammation, and an avid host immune response. ${ }^{160}$ Furthermore, triggering an antiangiogenic switch by the subconjunctival delivery of VEGFR-1 morpholine oligonucleotides, inducing alternative splicing of mbFlt-1 to sFlt-1, a VEGF-A quencher, increases murine corneal allograft survival in high-risk transplants by $27 \% .{ }^{161}$ This effect is believed to be the beneficial result of reduced free VEGF-A, leading to inhibition of hemeand lymph-angiogenesis, with a secondary decrease in trafficking of activated $\mathrm{T}$ cells into the graft.

Immune Response Modulation-Graft rejection is primarily attributed to an overwhelming immune response against antigens in the donor corneal graft. With key molecular and cellular players, such as activated APCs, namely DCs, plasmacytoid DCs, activated $\mathrm{T}$ cells, and pro-inflammatory cytokines, redirecting the immune response towards allotolerance becomes critical to graft survival. Towards that goal, several molecular candidates have been tested with a focus on efficient, targeted suppression of immunemediated graft rejection. Activated T cells are a turning point in the immune-mediated destruction of the allograft. Complete and effective activation of T cells relies upon two main cellular interactions: binding of T cell receptor/CD3 with MHC molecules on APCs, and interaction of T cell co-stimulatory molecule CD28 with B7 antigens on APCs (CD80 and CD86). ${ }^{162}$ Cytotoxic T-Lymphocyte Antigen 4 protein (CTLA4-Ig), a fusion protein that competitively inhibits the binding of $\mathrm{B} 7$ antigens with $\mathrm{CD} 28$, preventing activation of $\mathrm{T}$ cells through co-stimulation, can effectively prolong graft survival by intravenous delivery of adenoviral vectors expressing CTLA4-Ig on the day after transplantation. ${ }^{163,164}$ This degree of protection is contingent upon both the vector and mode of delivery applied, as evident by a meager improvement in graft survival, when the same gene was expressed by a minimalistic immunologically defined gene expression (MIDGE) vector, delivered by a gene gun to the corneal epithelium. ${ }^{165}$

Modulation of pro-inflammatory cytokines that mediate graft rejection is yet another approach for conferring graft survival. Adenoviral vectors have been used to deliver IL-10 and IL-12 to ovine corneas with a perceivably tangible increase in graft 
survival. ${ }^{20,107,141,166}$ However, corneal transduction ex vivo by adenoviral-mediated expression of TNF receptor fusion protein prior to allogeneic transplantation in rabbits only led to a modest increase in graft survival. ${ }^{167}$ Immunogenicity of this vector remains an impediment to effective immune suppression.

Indoleamine 2,3-dioxygenase (IDO), now thought to be implicated in fostering ocular immune privilege, ${ }^{168,169}$ leads to arrest of T cells in cell cycle phase G1 when activated, thereby facilitating tolerance. ${ }^{170}$ Lentivirus-mediated transduction of corneal endothelial cells ex vivo, delivering IDO prior to corneal transplantation, has been shown to significantly prolong corneal graft survival in mice. ${ }^{171}$

Rapamycin plays a promising role in promoting corneal graft survival. ${ }^{83,84}$ When delivered intraperitoneally in mice, 14 days prior to allogeneic corneal transplantation, grafts resulted in optical clarity, reduced neovascularization, and longer graft survival with an increase in Foxp3 gene expression. ${ }^{172}$ These findings are consistent with the effect of rapamycin in the presence of IL- 2 on circulating populations of inducible Foxp $3^{+}$regulatory T cells, which mediate inhibition of graft-versus-host disease. ${ }^{173}$ To maintain sustained immune suppression, measures such as rapamycin-loaded chitosan/polylactic acid (PLA) nanoparticles have been employed to increase allograft survival time. ${ }^{174}$

Anti-Apoptosis-Loss in corneal stromal and endothelial cell density results in graft failure following corneal transplantation. ${ }^{139,175-177}$ Corneal endothelial cells have limited proliferative capacity, therefore once lost, their contribution to maintaining corneal transparency is permanently compromised. Methods promoting longevity of corneal endothelial cells can ensure longer survival rates of corneal allografts, given that $25 \%$ of graft failures 15 years post-transplantation are linked to endothelial cell failure. ${ }^{4,140}$ Mammalian cell apoptosis is mediated by the death receptor (extrinsic) and mitochondrial (intrinsic) pathways. ${ }^{178}$ Successful inhibition of these apoptotic pathways through transfection of human corneal endothelial cells with $\mathrm{p} 35$ and Bcl- ${ }_{\mathrm{xL}}$ genes has proved to promote endothelial cell survival ex vivo, implicating their role in corneal endothelial gene therapy towards enhanced graft survival. ${ }^{139}$ Ex-vivo transduction of rat corneas with lentiviral vectors expressing programmed death ligand-1 (LV.PDL-1) significantly increased graft survival with a concomitant decrease in pro-inflammatory cytokines such as IL-6 and IFN- $\gamma$, as compared to control corneas treated with a GFP-expressing vector (LV.eGFP). ${ }^{19}$ Towards cytoprotective vector strategies that may reduce endothelial cell loss, calcium phospohate nanoparticles (CaP-NPs) present an efficient and non-toxic vehicle for transfection of corneal endothelial cells, a pertinent point to consider when recipient cells bear minimal proliferative potential and their loss in cell density is associated with graft rejection. ${ }^{92}$ Other than corneal endothelial cells, apoptosis of resident non-bone marrowderived stromal fibroblasts is also strongly correlated with the failure of corneal allografts, especially in an inflamed setting such as that of high-risk grafts, ${ }^{175}$ implicating the development of stromal fibroblast cell survival strategies in battling corneal graft rejection. Over the past decade, remarkable progress has been made in the investigation and development of gene therapy in corneal transplantation. These studies have been summarized in Table 1.

\section{DISCUSSION}

The ability to modify gene expression in the donor and recipient corneas is by far one of the most powerful strategies devised in the approach to tackling immune-mediated corneal allograft rejection. Corneal graft rejection, being a complex phenomenon with both local and systemic involvement, requires multi-faceted therapeutic strategies rather than unidimensional ones. First, sustained changes in protein expression, which can promote 
allotolerance through modulation of a combination of molecular and cellular players involved in angiogenesis, inflammation, alloantigen recognition, alloantigen presentation, $\mathrm{T}$ cell sensitization and proliferation, generation of memory and regulatory $\mathrm{T}$ cells, immune cell trafficking and effector $\mathrm{T}$ cell response, will hold the greatest promise in inhibiting immune-mediated graft rejection. Second, securing the most efficient, non-immunogenic, and sustainable vector and gene delivery method are critical to the success of gene-based therapeutic strategies. Hence, careful attention should be paid to vector characteristics for selection into large-scale studies.

In this new age of targeted gene therapy, vector engineering is picking up pace, recognizing the gravity and relevance of cell-specific gene therapy to clinical application. Towards this goal, vector engineering is becoming popular among scientists to ensure cell-specific gene transfer that can have greater relevance for large-scale clinical use. One method identified is to clone tissue-specific promoters into vectors of choice, ensuring targeted, cell-specific transgene delivery. ${ }^{179}$ While corneal epithelial- and stromal keratocyte-specific promoters, keratin 12 (K12) and keratocan (Kera3.2), have been designed and optimized for targeted transgene delivery to murine and rabbit corneal epithelial cells ${ }^{180,181}$ and stromal keratocytes, ${ }^{22,181}$ further work is needed to design and test corneal endothelium-specific promoters in vivo. Another method involves the cloning of an inducible strong promoter that can switch gene expression on or off based on the presence of other molecular factors. ${ }^{182,183}$ Recently, a glucocorticosteroid-inducible reporter (GRE5) cloned into a lentiviral vector expressing a plasmid for IL-10 successfully transduced into human corneas ex vivo demonstrated a rapid, sustained, nine-fold increase in IL-10 protein expression in the presence of dexamethasone, suggesting the utility of this method in the genetic modulation of corneal graft rejection, where steroids have remained the mainstay of medical management for the past 60 years. ${ }^{184}$ Recently, morpholine oligonucleotides have been designed to induce a molecular "anti-angiogenic" switch whereby it generates sFlt-1 through alternative splicing of Flt-1 pre-mRNA, leading to inhibition of corneal neovascularization, decreased corneal lymphangiogenesis, and increased corneal allograft survival. ${ }^{161,185-187}$

With 28 active gene therapy clinical trials for amelioration of diseases of the retina, glaucoma, and corneal wound healing, gene therapy is no longer a frontier of unknown or speculative significance in the field of clinical ophthalmology. While retinal disease has seen significant progress in the development and application of gene-based measures, ${ }^{188-192}$ the application of genetic tools to treat and manage corneal disease is still in its infancy and yet to experience further transition from experimental investigation to clinical trials. New horizons are beginning to appear in the realm of corneal gene therapy with greater interest in exploring the functions of microRNAs (miRNAs) in the cornea. It is therefore worthwhile to postulate that investigation into miRNA-mediated modulation of corneal angiogenesis and immune signaling pathways in conjunction with multiple-gene regulation present the future of gene therapy in allogeneic graft survival. Of such therapies to spearhead into clinical trials will be those that will best navigate the immunological milieu to normalcy, while restoring corneal transparency, and modulating or balancing immune cell sub-populations, with minimal offtarget effects.

\section{REFERENCES}

1. 2011-2012 Year in Review: Focused on Restoring Sight Worldwide; Eye Bank Association of America. 2012. p. 1-13.Available at: http://issuu.com/moiremarketing/docs/ebaa-2011-12yir-final? $\mathrm{e}=1631814 / 2738036$

2. Thompson RW Jr, Price MO, Bowers PJ, et al. Long-term graft survival after penetrating keratoplasty. Ophthalmology. 2003; 110:1396-1402. [PubMed: 12867398] 
3. Niederkorn JY. Immune privilege and immune regulation in the eye. Adv Immunol. 1990; 48:191226. [PubMed: 2190450]

4. Williams KA, Lowe M, Bartlett $\mathrm{C}$, et al. Risk factors for human corneal graft failure within the Australian corneal graft registry. Transplantation. 2008; 86:1720-1724. [PubMed: 19104411]

5. Guilbert E, Bullet J, Sandali O, et al. Long-term rejection incidence and reversibility after penetrating and lamellar keratoplasty. Am J Ophthalmol. 2013; 155:560-569. [PubMed: 23218931]

6. Streilein JW, Yamada J, Dana MR, et al. Anterior chamber-associated immune deviation, ocular immune privilege, and orthotopic corneal allografts. Transplant Proc. 1999; 31:1472-1475. [PubMed: 10330973]

7. Alldredge OC, Krachmer JH. Clinical types of corneal transplant rejection: their manifestations, frequency, pre-operative correlates, and treatment. Arch Ophthalmol. 1981; 99:599-604. [PubMed: 7013739]

8. Port FK, Dykstra DM, Merion RM, et al. Trends and results for organ donation and transplantation in the United States, 2004. Am J Transplant. 2005; 5:843-849. [PubMed: 15760412]

9. Hamrah, P.; Mantopoulos, D.; Akhtar, J.; Djalilian, AR. Immunologically high-risk penetrating keratoplasty. In: Krachmer, J.; Mannis, MJ.; Jolland, EJ., editors. Cornea. 3rd ed. Mosby: St. Louis; 2010. p. 1495-1510.

10. Ling S, Lin H, Xiang D, et al. Clinical and experimental research of corneal lymphangiogenesis after keratoplasty. Ophthalmologica. 2008; 222:308-316. [PubMed: 18617753]

11. Cursiefen C, Cao J, Chen L, et al. Inhibition of hemangiogenesis and lymphangiogenesis after normal-risk corneal transplantation by neutralizing VEGF promotes graft survival. Invest Ophthalmol Vis Sci. 2004; 45:2666-2673. [PubMed: 15277490]

12. Bachmann BO, Luetjen-Drecoll E, Bock F, et al. Transient postoperative vascular endothelial growth factor (VEGF)-neutralisation improves graft survival in corneas with partly regressed inflammatory neovascularisation. Br J Ophthalmol. 2009; 93:1075-1080. [PubMed: 19224901]

13. Hos D, Bock F, Dietrich T, et al. Inflammatory corneal (lymph)angiogenesis is blocked by VEGFR-tyrosine kinase inhibitor ZK 261,991, resulting in improved graft survival after corneal transplantation. Invest Ophthalmol Vis Sci. 2008; 49:1836-1842. [PubMed: 18436817]

14. Bachmann B, Taylor RS, Cursiefen C. Corneal neovascularization as a risk factor for graft failure and rejection after keratoplasty: an evidence-based meta-analysis. Ophthalmology. 2010; 117:1300-1305. [PubMed: 20605214]

15. Dana MR, Streilein JW. Loss and restoration of immune privilege in eyes with corneal neovascularization. Invest Ophthalmol Vis Sci. 1996; 37:2485-2494. [PubMed: 8933765]

16. Dana MR. Angiogenesis and lymphangiogenesis-implications for corneal immunity. Semin Ophthalmol. 2006; 21:19-22. [PubMed: 16517440]

17. Michael Edelstein. Gene Therapy Clinical Trials Worldwide. John Wiley and Sons Ltd; 2012. Available at: http://www.abedia.com/wiley/search_results.php?

TrialCountry $=\&$ RefResults $=\&$ CategoryMain $=$ Ocular + diseases $\&$ Indication $=\&$ Vector $=\&$ Genes $=\&$ GeneTypes $=\&$ Phase $=\&$ Status $=\&$ FinalApprYear $=\& S$ ubmit $=\%$ A0\% A0Search $\%$ A0\%A0

18. Ginn SL, Alexander IE, Edelstein ML, et al. Gene therapy clinical trials worldwide to 2012: an update. J Gene Med. 2013; 15:65-77. [PubMed: 23355455]

19. Nosov M, Wilk M, Morcos M, et al. Role of lentivirus-mediated overexpression of programmed death-ligand 1 on corneal allograft survival. Am J Transplant. 2012; 12:1313-1322. [PubMed: 22300371]

20. Gong N, Pleyer U, Volk HD, et al. Effects of local and systemic viral interleukin-10 gene transfer on corneal allograft survival. Gene Ther. 2007; 14:484-490. [PubMed: 17093506]

21. Hippert C, Ibanes S, Serratrice N, et al. Corneal transduction by intra-stromal injection of AAV vectors in vivo in the mouse and ex vivo in human explants. PLoS One. 2012; 7:e35318. [PubMed: 22523585]

22. Carlson EC, Liu CY, Yang X, et al. In vivo gene delivery and visualization of corneal stromal cells using an adenoviral vector and keratocyte-specific promoter. Invest Ophthalmol Vis Sci. 2004; 45:2194-2200. [PubMed: 15223795] 
23. Chong EM, Dana MR. Graft failure IV. Immunologic mechanisms of corneal transplant rejection. Int Ophthalmol. 2008; 28:209-222. [PubMed: 17673946]

24. Streilein JW. Immunobiology and immunopathology of corneal transplantation. Chem Immunol. 1999; 73:186-206. [PubMed: 10590580]

25. Yamada J, Streilein JW. Induction of anterior chamber-associated immune deviation by corneal allografts placed in the anterior chamber. Invest Ophthalmol Vis Sci. 1997; 38:2833-2843. [PubMed: 9418737]

26. Hamrah P, Liu Y, Zhang Q, et al. The corneal stroma is endowed with a significant number of resident dendritic cells. Invest Ophthalmol Vis Sci. 2003; 44:581-589. [PubMed: 12556386]

27. Hamrah P, Zhang Q, Liu Y, et al. Novel characterization of MHC class II-negative population of resident corneal Langerhans cell-type dendritic cells. Invest Ophthalmol Vis Sci. 2002; 43:639_ 646. [PubMed: 11867578]

28. Qazi, Y.; Turhan, A.; Hamrah, P. Trafficking of immune cells in the cornea and ocular surface. In: Rumelt, S., editor. Advances in Ophthalmology. InTech: Rijeka; 2012. p. 79-104.

29. Yamagami S, Kawashima H, Tsuru T, et al. Role of Fas-Fas ligand interactions in the immunorejection of allogeneic mouse corneal transplants. Transplantation. 1997; 64:1107-1111. [PubMed: 9355824]

30. Stuart PM, Griffith TS, Usui N, et al. CD95 ligand (FasL)-induced apoptosis is necessary for corneal allograft survival. J Clin Invest. 1997; 99:396-402. [PubMed: 9022072]

31. Liechtenstein T, Dufait I, Bricogne C, et al. PD-L1/PD-1 co-stimulation, a brake for T cell activation and a $\mathrm{T}$ cell differentiation signal. J Clin Cell Immunol. 2012; S12:006. [PubMed: 23525238]

32. Shen L, Jin Y, Freeman GJ, et al. The function of donor versus recipient programmed death-ligand 1 in corneal allograft survival. J Immunol. 2007; 179:3672-3679. [PubMed: 17785803]

33. Yang W, Li H, Chen PW, et al. PD-L1 expression on human ocular cells and its possible role in regulating immune-mediated ocular inflammation. Invest Ophthalmol Vis Sci. 2009; 50:273-280. [PubMed: 18791172]

34. Patsoukis N, Sari D, Boussiotis VA. PD-1 inhibits T cell proliferation by upregulating p27 and p15 and suppressing Cdc25A. Cell Cycle. 2012; 11:4305-4309. [PubMed: 23032366]

35. Jiang L, He H, Yang P, et al. Splenic CD8+ T cells secrete TGF-beta1 to exert suppression in mice with anterior chamber-associated immune deviation. Graefes Arch Clin Exp Ophthalmol. 2009; 247:87-92. [PubMed: 18797912]

36. Stein-Streilein J, Streilein JW. Anterior chamber associated immune deviation (ACAID): regulation, biological relevance, and implications for therapy. Int Rev Immunol. 2002; 21:123152. [PubMed: 12424840]

37. Wilbanks GA, Streilein JW. Studies on the induction of anterior chamber-associated immune deviation (ACAID). 1. Evidence that an antigen-specific, ACAID-inducing, cell-associated signal exists in the peripheral blood. J Immunol. 1991; 146:2610-2617. [PubMed: 1707912]

38. Kaplan HJ, Streilein JW. Immune response to immunization via the anterior chamber of the eye. I. F. lymphocyte-induced immune deviation. J Immunol. 1977; 118:809-814. [PubMed: 321682]

39. Kaplan HJ, Streilein JW. Immune response to immunization via the anterior chamber of the eye. II. An analysis of F1 lymphocyte-induced immune deviation. J Immunol. 1978; 120:689-693. [PubMed: 632581]

40. Streilein JW. Anterior chamber associated immune deviation: the privilege of immunity in the eye. Surv Ophthalmol. 1990; 35:67-73. [PubMed: 2204129]

41. Yao YF, Inoue Y, Miyazaki D, et al. Correlation of anterior chamber-associated immune deviation with suppression of corneal epithelial rejection in mice. Invest Ophthalmol Vis Sci. 1997; 38:292300. [PubMed: 9040461]

42. Forrester JV, Xu H, Kuffova L, et al. Dendritic cell physiology and function in the eye. Immunol Rev. 2010; 234:282-304. [PubMed: 20193026]

43. Hamrah P, Liu Y, Zhang Q, et al. Alterations in corneal stromal dendritic cell phenotype and distribution in inflammation. Arch Ophthalmol. 2003; 121:1132-1140. [PubMed: 12912691] 
44. Liu Y, Hamrah P, Zhang Q, et al. Draining lymph nodes of corneal transplant hosts exhibit evidence for donor major histocompatibility complex (MHC) class II-positive dendritic cells derived from MHC class II-negative grafts. J Exp Med. 2002; 195:259-268. [PubMed: 11805152]

45. Khan A, Fu H, Tan LA, et al. Dendritic cell modification as a route to inhibiting corneal graft rejection by the indirect pathway of allorecognition. Eur J Immunol. 2012; 43:734-746. [PubMed: 23212959]

46. Barcia RN, Dana MR, Kazlauskas A. Corneal graft rejection is accompanied by apoptosis of the endothelium and is prevented by gene therapy with bcl-xL. Am J Transplant. 2007; 7:2082-2089. [PubMed: 17614980]

47. Mellman I, Steinman RM. Dendritic cells: specialized and regulated antigen processing machines. Cell. 2001; 106:255-258. [PubMed: 11509172]

48. Huq S, Liu Y, Benichou G, et al. Relevance of the direct pathway of sensitization in corneal transplantation is dictated by the graft bed microenvironment. J Immunol. 2004; 173:4464-4469. [PubMed: 15383577]

49. Boisgerault F, Liu Y, Anosova N, et al. Differential roles of direct and indirect allorecognition pathways in the rejection of skin and corneal transplants. Transplantation. 2009; 87:16-23. [PubMed: 19136886]

50. Sano Y, Ksander BR, Streilein JW. Langerhans cells, orthotopic corneal allografts, and direct and indirect pathways of T-cell allorecognition. Invest Ophthalmol Vis Sci. 2000; 41:1422-1431. [PubMed: 10798658]

51. Williams KA, Coster DJ. The immunobiology of corneal transplantation. Transplantation. 2007; 84:806-813. [PubMed: 17984831]

52. Dana MR, Qian Y, Hamrah P. Twenty-five-year panorama of corneal immunology: emerging concepts in the immu-nopathogenesis of microbial keratitis, peripheral ulcerative keratitis, and corneal transplant rejection. Cornea. 2000; 19:625-643. [PubMed: 11009315]

53. Yamagami S, Amano S. Role of resident corneal leukocytes and draining cervical lymph nodes in corneal allograft rejection. Cornea. 2003; 22:S61-S65. [PubMed: 14703709]

54. Sano Y, Streilein JW, Ksander BR. Detection of minor alloantigen-specific cytotoxic T cells after rejection of murine orthotopic corneal allografts: evidence that graft antigens are recognized exclusively via the "indirect pathway". Transplantation. 1999; 68:963-970. [PubMed: 10532535]

55. Yamagami S, Miyazaki D, Ono SJ, et al. Differential chemokine gene expression in corneal transplant rejection. Invest Ophthalmol Vis Sci. 1999; 40:2892-2897. [PubMed: 10549649]

56. Yamagami S, Hamrah P, Zhang Q, et al. Early ocular chemokine gene expression and leukocyte infiltration after high-risk corneal transplantation. Mol Vis. 2005; 11:632-640. [PubMed: 16145544]

57. Yamagami S, Isobe M, Tsuru T. Characterization of cyto-kine profiles in corneal allograft with anti-adhesion therapy. Transplantation. 2000; 69:1655-1659. [PubMed: 10836377]

58. Hegde S, Niederkorn JY. The role of cytotoxic T lymphocytes in corneal allograft rejection. Invest Ophthalmol Vis Sci. 2000; 41:3341-3347. [PubMed: 11006223]

59. Yamada J, Ksander BR, Streilein JW. Cytotoxic T cells play no essential role in acute rejection of orthotopic corneal allografts in mice. Invest Ophthalmol Vis Sci. 2001; 42:386-392. [PubMed: 11157871]

60. Hegde S, Beauregard C, Mayhew E, et al. CD4(+) T-cell-mediated mechanisms of corneal allograft rejection: role of Fas-induced apoptosis. Transplantation. 2005; 79:23-31. [PubMed: 15714165]

61. Birnbaum F, Bohringer D, Sokolovska Y, et al. Immunosuppression with cyclosporine A and mycophenolate mofetil after penetrating high-risk keratoplasty: a retrospective study. Transplantation. 2005; 79:964-968. [PubMed: 15849551]

62. Costa DC, de Castro RS, Kara-Jose N. Case-control study of subconjunctival triamcinolone acetonide injection vs intravenous methylprednisolone pulse in the treatment of endothelial corneal allograft rejection. Eye (Lond). 2009; 23:708-714. [PubMed: 18820657]

63. Yamaguchi, T.; Hamrah, P. Immunotherapy of ocular surface diseases and graft rejection. In: Copland, R.; Afshari, NA., editors. Copland and Afshari's Principles and Practice of Cornea. New Delhi: Jaypee Brothers; 2013. p. 580-600. 
64. Acar BT, Halili E, Acar S. The effect of different doses of subconjunctival bevacizumab injection on corneal neovascularization. Int Ophthalmol. 2013

65. Petsoglou C, Balaggan KS, Dart JK, et al. Subconjunctival bevacizumab induces regression of corneal neovascularisation: a pilot randomised placebo-controlled double-masked trial. Br J Ophthalmol. 2013; 97:28-32. [PubMed: 23087419]

66. Jeong JH, Chun YS, Kim ES, et al. Compensatory growth factor and cytokine response in tears after subconjunctival bevacizumab injection. Cornea. 2011; 30:1071-1077. [PubMed: 21775887]

67. Dastjerdi MH, Saban DR, Okanobo A, et al. Effects of topical and subconjunctival bevacizumab in high-risk corneal transplant survival. Invest Ophthalmol Vis Sci. 2010; 51:2411-2417. [PubMed: 19892863]

68. Zaki AA, Farid SF. Subconjunctival bevacizumab for corneal neovascularization. Acta Ophthalmol. 2010; 88:868-871. [PubMed: 19519730]

69. Awadein A. Subconjunctival bevacizumab for vascularized rejected corneal grafts. J Cataract Refract Surg. 2007; 33:1991-1993. [PubMed: 17964413]

70. Erdurmus M, Totan Y. Subconjunctival bevacizumab for corneal neovascularization. Graefes Arch Clin Exp Ophthalmol. 2007; 245:1577-1579. [PubMed: 17458556]

71. Reinhard T, Mayweg S, Reis A, et al. Topical FK506 as immunoprophylaxis after allogeneic penetrating normal-risk keratoplasty: a randomized clinical pilot study. Transpl Int. 2005; 18:193197. [PubMed: 15691272]

72. Dhaliwal JS, Mason BF, Kaufman SC. Long-term use of topical tacrolimus (FK506) in high-risk penetrating keratoplasty. Cornea. 2008; 27:488-493. [PubMed: 18434855]

73. Sloper CM, Powell RJ, Dua HS. Tacrolimus (FK506) in the management of high-risk corneal and limbal grafts. Ophthalmology. 2001; 108:1838-1844. [PubMed: 11581059]

74. Joseph A, Raj D, Shanmuganathan V, et al. Tacrolimus immunosuppression in high-risk corneal grafts. Br J Ophthalmol. 2007; 91:51-55. [PubMed: 16956911]

75. Sinha R, Jhanji V, Verma K, et al. Efficacy of topical cyclosporine A $2 \%$ in prevention of graft rejection in high-risk keratoplasty: a randomized controlled trial. Graefes Arch Clin Exp Ophthalmol. 2010; 248:1167-1172. [PubMed: 20414783]

76. Belin MW, Bouchard CS, Frantz S, et al. Topical cyclosporine in high-risk corneal transplants. Ophthalmology. 1989; 96:1144-1150. [PubMed: 2797718]

77. Cosar CB, Laibson PR, Cohen EJ, et al. Topical cyclosporine in pediatric keratoplasty. Eye Contact Lens. 2003; 29:103-107. [PubMed: 12695714]

78. Miller K, Huber C, Niederwieser D, et al. Successful engraftment of high-risk corneal allografts with short-term immunosuppression with cyclosporine. Transplantation. 1988; 45:651-653. [PubMed: 3279589]

79. Poon A, Constantinou M, Lamoureux E, et al. Topical Cyclosporin A in the treatment of acute graft rejection: a randomized controlled trial. Clin Experiment Ophthalmol. 2008; 36:415-421. [PubMed: 18939344]

80. Althaus C, Dagres E, Reinhard T, et al. Cyclosporin-A and its metabolites in the anterior chamber after topical and systemic application as determined with high-performance liquid chromatography-electrospray mass spectrometry. Ger J Ophthalmol. 1996; 5:189-194. [PubMed: 8854101]

81. Reis A, Reinhard T, Voiculescu A, et al. Mycophenolate mofetil versus cyclosporin A in high risk keratoplasty patients: a prospectively randomised clinical trial. Br J Ophthalmol. 1999; 83:12681271. [PubMed: 10535855]

82. Reinhard T, Mayweg S, Sokolovska Y, et al. Systemic mycophenolate mofetil avoids immune reactions in penetrating high-risk keratoplasty: preliminary results of an ongoing prospectively randomized multicentre study. Transpl Int. 2005; 18:703-708. [PubMed: 15910297]

83. Birnbaum F, Reis A, Bohringer D, et al. An open prospective pilot study on the use of rapamycin after penetrating high-risk keratoplasty. Transplantation. 2006; 81:767-772. [PubMed: 16534481]

84. Chatel MA, Larkin DF. Sirolimus and mycophenolate as combination prophylaxis in corneal transplant recipients at high rejection risk. Am J Ophthalmol. 2010; 150:179-184. [PubMed: 20570235] 
85. Ippoliti G, Fronterre A. Usefulness of CD3 or CD6 anti-T monoclonal antibodies in the treatment of acute corneal graft rejection. Transplant Proc. 1989; 21:3133-3134. [PubMed: 2523173]

86. Ippoliti G, Fronterre A. Use of locally injected anti-T monoclonal antibodies in the treatment of acute corneal graft rejection. Transplant Proc. 1987; 19:2579-2580. [PubMed: 3274568]

87. Schmitz K, Hitzer S, Behrens-Baumann W. Immunsuppression durch Kombinationstherapie mit Basiliximab und Ciclosporin bei Hochrisikokeratoplastik. Eine Pilotstudie [Immune suppression by combination therapy with basiliximab and cyclosporin in high risk keratoplasty. A pilot study]. Ophthalmologe. 2002; 99:38-45. [PubMed: 11840795]

88. Birnbaum F, Jehle T, Schwartzkopff J, et al. Basiliximab als Monotherapie nach perforierender Risikokeratoplastik: eine prospektive randomisierte Pilotstudie [Basiliximab following penetrating risk-keratoplasty: a prospective randomized pilot study]. Klin Monbl Augenheilkd. 2008; 225:6265. [PubMed: 18236372]

89. Hori J, Joyce NC, Streilein JW. Immune privilege and immunogenicity reside among different layers of the mouse cornea. Invest Ophthalmol Vis Sci. 2000; 41:3032-3042. [PubMed: 10967061]

90. Cursiefen C. Immune privilege and angiogenic privilege of the cornea. Chem Immunol Allergy. 2007; 92:50-57. [PubMed: 17264482]

91. Bertelmann E. Genetic manipulation of corneal endothelial cells: transfection and viral transduction. Methods Mol Biol. 2009; 467:229-239. [PubMed: 19301674]

92. Hu J, Kovtun A, Tomaszewski A, et al. A new tool for the transfection of corneal endothelial cells: calcium phosphate nanoparticles. Acta Biomater. 2012; 8:1156-1163. [PubMed: 21982848]

93. Qazi Y, Stagg B, Singh N, et al. Nanoparticle-mediated delivery of shRNA.VEGF-a plasmids regresses corneal neovascularization. Invest Ophthalmol Vis Sci. 2012; 53:2837-2844. [PubMed: 22467572]

94. Baker AH. Designing gene delivery vectors for cardiovascular gene therapy. Prog Biophys Mol Biol. 2004; 84:279-299. [PubMed: 14769440]

95. Surace EM, Auricchio A. Adeno-associated viral vectors for retinal gene transfer. Prog Retin Eye Res. 2003; 22:705-719. [PubMed: 14575721]

96. Shenk, T. Adenoviridae: The viruses and their teplication. In: Fields, B.; Knipe, DM.; Howley, PM., editors. Fields Virology. 3rd ed. Philadelphia: Lippincott-Raven; 1996. p. 2111-2148.

97. Petrie NC, Yao F, Eriksson E. Gene therapy in wound healing. Surg Clin North Am. 2003; 83:597-616. [PubMed: 12822728]

98. Bergelson JM, Cunningham JA, Droguett G, et al. Isolation of a common receptor for Coxsackie B viruses and adenoviruses 2 and 5. Science. 1997; 275:1320-1323. [PubMed: 9036860]

99. Tomko RP, Xu R, Philipson L. HCAR and MCAR: the human and mouse cellular receptors for subgroup C adenoviruses and group B coxsackieviruses. Proc Natl Acad Sci U S A. 1997; 94:3352-3356. [PubMed: 9096397]

100. Wickham TJ, Mathias P, Cheresh DA, et al. Integrins alpha v beta 3 and alpha v beta 5 promote adenovirus internalization but not virus attachment. Cell. 1993; 73:309-319. [PubMed: 8477447]

101. Qian Y, Leong FL, Kazlauskas A, et al. Ex vivo adenovirus-mediated gene transfer to corneal graft endothelial cells in mice. Invest Ophthalmol Vis Sci. 2004; 45:2187-2193. [PubMed: 15223794]

102. Araki-Sasaki K, Ohashi Y, Sasabe T, et al. An SV40-immortalized human corneal epithelial cell line and its characterization. Invest Ophthalmol Vis Sci. 1995; 36:614-621. [PubMed: 7534282]

103. Mashhour B, Couton D, Perricaudet M, et al. In vivo adenovirus-mediated gene transfer into ocular tissues. Gene Ther. 1994; 1:122-126. [PubMed: 7584067]

104. Budenz DL, Bennett J, Alonso L, et al. In vivo gene transfer into murine corneal endothelial and trabecular meshwork cells. Invest Ophthalmol Vis Sci. 1995; 36:2211-2215. [PubMed: 7558714]

105. Larkin DF, Oral HB, Ring CJ, et al. Adenovirus-mediated gene delivery to the corneal endothelium. Transplantation. 1996; 61:363-370. [PubMed: 8610341]

106. Tsubota K, Inoue H, Ando K, et al. Adenovirus-mediated gene transfer to the ocular surface epithelium. Exp Eye Res. 1998; 67:531-538. [PubMed: 9878215] 
107. Klebe S, Sykes PJ, Coster DJ, et al. Prolongation of sheep corneal allograft survival by ex vivo transfer of the gene encoding interleukin-10. Transplantation. 2001; 71:1214-1220. [PubMed: 11397952]

108. Borras T, Tamm ER, Zigler JS Jr. Ocular adenovirus gene transfer varies in efficiency and inflammatory response. Invest Ophthalmol Vis Sci. 1996; 37:1282-1293. [PubMed: 8641831]

109. Borras T, Gabelt BT, Klintworth GK, et al. Non-invasive observation of repeated adenoviral GFP gene delivery to the anterior segment of the monkey eye in vivo . J Gene Med. 2001; 3:437-449. [PubMed: 11601757]

110. Oral HB, Larkin DF, Fehervari Z, et al. Ex vivo adenovirus-mediated gene transfer and immunomodulatory protein production in human cornea. Gene Ther. 1997; 4:639-647. [PubMed: 9282165]

111. Muzyczka, N.; Berns, KI. Parvoviridae: The viruses and their replication. In: Knipe, D.; Howley, PM., editors. Fields Virology. 4th ed. Philadelphia: Lippincott Williams and Wilkins; 2001. p. 2327-2360.

112. Lu Y. Recombinant adeno-associated virus as delivery vector for gene therapy: a review. Stem Cells Dev. 2004; 13:133-145. [PubMed: 15068701]

113. Grimm D, Kay MA, Kleinschmidt JA. Helper virus-free, optically controllable, and two-plasmidbased production of adeno-associated virus vectors of serotypes 1 to 6 . Mol Ther. 2003; 7:839850. [PubMed: 12788658]

114. Rutledge EA, Halbert CL, Russell DW. Infectious clones and vectors derived from adenoassociated virus (AAV) serotypes other than AAV type 2. J Virol. 1998; 72:309-319. [PubMed: 9420229]

115. Summerford C, Samulski RJ. Membrane-associated heparan sulfate proteoglycan is a receptor for adeno-associated virus type 2 virions. J Virol. 1998; 72:1438-1445. [PubMed: 9445046]

116. Walters RW, Yi SM, Keshavjee S, et al. Binding of adeno-associated virus type 5 to 2,3-linked sialic acid is required for gene transfer. J Biol Chem. 2001; 276:20610-20616. [PubMed: 11262413]

117. Rabinowitz JE, Rolling F, Li C, et al. Cross-packaging of a single adeno-associated virus (AAV) type 2 vector genome into multiple AAV serotypes enables transduction with broad specificity. $\mathrm{J}$ Virol. 2002; 76:791-801. [PubMed: 11752169]

118. Mohan RR, Sharma A, Netto MV, et al. Gene therapy in the cornea. Prog Retin Eye Res. 2005; 24:537-559. [PubMed: 15955719]

119. Mohan RR, Schultz GS, Hong JW, et al. Gene transfer into rabbit keratocytes using AAV and lipid-mediated plasmid DNA vectors with a lamellar flap for stromal access. Exp Eye Res. 2003; 76:373-383. [PubMed: 12573666]

120. Hudde T, Rayner SA, De Alwis M, et al. Adeno-associated and herpes simplex viruses as vectors for gene transfer to the corneal endothelium. Cornea. 2000; 19:369-373. [PubMed: 10832701]

121. Tsai ML, Chen SL, Chou PI, et al. Inducible adeno-associated virus vector-delivered transgene expression in corneal endothelium. Invest Ophthalmol Vis Sci. 2002; 43:751-757. [PubMed: 11867594]

122. Gao GP, Alvira MR, Wang L, et al. Novel adeno-associated viruses from rhesus monkeys as vectors for human gene therapy. Proc Natl Acad Sci U S A. 2002; 99:11854-11859. [PubMed: 12192090]

123. Sharma A, Ghosh A, Hansen ET, et al. Transduction efficiency of AAV 2/6, 2/8 and 2/9 vectors for delivering genes in human corneal fibroblasts. Brain Res Bull. 2010; 81:273-278. [PubMed: 19616080]

124. Duan D, Yue Y, Yan Z, et al. A new dual-vector approach to enhance recombinant adenoassociated virus-mediated gene expression through intermolecular cis activation. Nat Med. 2000; 6:595-598. [PubMed: 10802719]

125. Sun L, Li J, Xiao X. Overcoming adeno-associated virus vector size limitation through viral DNA hetero-dimerization. Nat Med. 2000; 6:599-602. [PubMed: 10802720]

126. Petrs-Silva H, Dinculescu A, Li Q, et al. Novel properties of tyrosine-mutant AAV2 vectors in the mouse retina. Mol Ther. 2011; 19:293-301. [PubMed: 21045809] 
127. Petrs-Silva H, Dinculescu A, Li Q, et al. High-efficiency transduction of the mouse retina by tyrosine-mutant AAV serotype vectors. Mol Ther. 2009; 17:463-471. [PubMed: 19066593]

128. Zhong L, Li B, Jayandharan G, et al. Tyrosine-phosphor-ylation of AAV2 vectors and its consequences on viral intracellular trafficking and transgene expression. Virology. 2008; 381:194-202. [PubMed: 18834608]

129. Zhong L, Li B, Mah CS, et al. Next generation of adeno-associated virus 2 vectors: point mutations in tyrosines lead to high-efficiency transduction at lower doses. Proc Natl Acad Sci U S A. 2008; 105:7827-7832. [PubMed: 18511559]

130. Mohan RR, Tovey JC, Sharma A, et al. Gene therapy in the cornea: 2005-present. Prog Retin Eye Res. 2012; 31:43-64. [PubMed: 21967960]

131. Clements JE, Zink MC. Molecular biology and pathogenesis of animal lentivirus infections. Clin Microbiol Rev. 1996; 9:100-117. [PubMed: 8665473]

132. Cullen BR, Greene WC. Functions of the auxiliary gene products of the human immunodeficiency virus type 1. Virology. 1990; 178:1-5. [PubMed: 2202146]

133. Maddon PJ, McDougal JS, Clapham PR, et al. HIV infection does not require endocytosis of its receptor, CD4. Cell. 1988; 54:865-874. [PubMed: 3261635]

134. Maddon PJ, Dalgleish AG, McDougal JS, et al. The T4 gene encodes the AIDS virus receptor and is expressed in the immune system and the brain. Cell. 1986; 47:333-348. [PubMed: 3094962]

135. McDougal JS, Maddon PJ, Dalgleish AG, et al. The T4 glycoprotein is a cell-surface receptor for the AIDS virus. Cold Spring Harb Symp Quant Biol. 1986; 51:703-711. [PubMed: 3495395]

136. Wang X, Appukuttan B, Ott S, et al. Efficient and sustained transgene expression in human corneal cells mediated by a lentiviral vector. Gene Titer. 2000; 7:196-200.

137. Bainbridge JW, Stephens C, Parsley K, et al. In vivo gene transfer to the mouse eye using an HIV-based lentiviral vector; efficient long-term transduction of corneal endothelium and retinal pigment epithelium. Gene Titer. 2001; 8:1665-1668.

138. Takahashi K, Luo T, Saishin Y, et al. Sustained transduction of ocular cells with a bovine immunodeficiency viral vector. Hum Gene Ther. 2002; 13:1305-1316. [PubMed: 12162813]

139. Fuchsluger TA, Jurkunas U, Kazlauskas A, et al. Corneal endothelial cells are protected from apoptosis by gene therapy. Hum Gene Ther. 2011; 22:549-558. [PubMed: 21158568]

140. Fuchsluger TA, Jurkunas U, Kazlauskas A, et al. Anti-apoptotic gene therapy prolongs survival of corneal endothelial cells during storage. Gene Ther. 2011; 18:778-787. [PubMed: 21412281]

141. Parker DG, Coster DJ, Brereton HM, et al. Lentivirus-mediated gene transfer of interleukin 10 to the ovine and human cornea. Clin Experiment Ophthalmol. 2010; 38:405-413. [PubMed: 20491805]

142. Contreras-Ruiz L, de la Fuente M, Garcia-Vazquez C, et al. Ocular tolerance to a topical formulation of hyaluronic acid and chitosan-based nanoparticles. Cornea. 2010; 29:550-558. [PubMed: 20335805]

143. Rafie F, Javadzadeh Y, Javadzadeh AR, et al. In vivo evaluation of novel nanoparticles containing dexamethasone for ocular drug delivery on rabbit eye. Curr Eye Res. 2010; 35:10811089. [PubMed: 20961207]

144. Farjo R, Skaggs J, Quiambao AB, et al. Efficient non-viral ocular gene transfer with compacted DNA nanoparticles. PLoS One. 2006; 1:e38. [PubMed: 17183666]

145. Bourges JL, Gautier SE, Delie F, et al. Ocular drug delivery targeting the retina and retinal pigment epithelium using polylactide nanoparticles. Invest Ophthalmol Vis Sci. 2003; 44:35623569. [PubMed: 12882808]

146. Cai X, Conley SM, Nash Z, et al. Gene delivery to mitotic and postmitotic photoreceptors via compacted DNA nanoparticles results in improved phenotype in a mouse model of retinitis pigmentosa. Faseb J. 2010; 24:1178-1191. [PubMed: 19952284]

147. Ding XQ, Quiambao AB, Fitzgerald JB, et al. Ocular delivery of compacted DNA-nanoparticles does not elicit toxicity in the mouse retina. PLoS One. 2009; 4:e7410. [PubMed: 19823583]

148. Ziady AG, Gedeon CR, Muhammad O, et al. Minimal toxicity of stabilized compacted DNA nanoparticles in the murine lung. Mol Ther. 2003; 8:948-956. [PubMed: 14664797] 
149. Seyfoddin A, Al-Kassas R. Development of solid lipid nanoparticles and nanostructured lipid carriers for improving ocular delivery of acyclovir. Drug Dev Ind Pharm. 2013; 39:508-519. [PubMed: 22424312]

150. Basaran E, Demirel M, Sirmagul B, et al. Polymeric cyclosporine-A nanoparticles for ocular application. J Biomed Nanotechnol. 2011; 7:714-723. [PubMed: 22195490]

151. Han Z, Conley SM, Makkia R, et al. Comparative analysis of DNA nanoparticles and AAVs for ocular gene delivery. PLoS One. 2012; 7:e52189. [PubMed: 23272225]

152. Konstan MW, Davis PB, Wagener JS, et al. Compacted DNA nanoparticles administered to the nasal mucosa of cystic fibrosis subjects are safe and demonstrate partial to complete cystic fibrosis transmembrane regulator reconstitution. Hum Gene Ther. 2004; 15:1255-1269. [PubMed: 15684701]

153. Qazi Y, Stagg B, Ambati BK. Nanoparticles in ophthalmic medicine. International Journal of Green Nanotechnology: Biomedicine. 2009; 1:B3-B8.

154. Jain A, Gulbake A, Shilpi S, et al. Development of surface-functionalised nanoparticles for FGF2 receptor-based solid tumour targeting. J Microencapsul. 2012; 29:95-102. [PubMed: 22126313]

155. Lu J, Shi M, Shoichet MS. Click chemistry functionalized polymeric nanoparticles target corneal epithelial cells through RGD-cell surface receptors. Bioconjug Chem. 2009; 20:87-94. [PubMed: 19099361]

156. Kukowska-Latallo JF, Bielinska AU, Johnson J, et al. Efficient transfer of genetic material into mammalian cells using Starburst polyamidoamine dendrimers. Proc Natl Acad Sci U S A. 1996; 93:4897-4902. [PubMed: 8643500]

157. Roberts JC, Bhalgat MK, Zera RT. Preliminary biological evaluation of polyamidoamine (PAMAM) starburst dendrimers. J Biomed Mater Res. 1996; 30:53-65. [PubMed: 8788106]

158. Hudde T, Rayner SA, Comer RM, et al. Activated polyamidoamine dendrimers, a non-viral vector for gene transfer to the corneal endothelium. Gene Ther. 1999; 6:939-943. [PubMed: 10505120]

159. Tang XL, Sun JF, Wang XY, et al. Blocking neuropilin-2 enhances corneal allograft survival by selectively inhibiting lymphangiogenesis on vascularized beds. Mol Vis. 2010; 16:2354-2361. [PubMed: 21139694]

160. Cho YK, Uehara H, Young JR, et al. Flt23k nanoparticles offer additive benefit in graft survival and anti-angiogenic effects when combined with triamcinolone. Invest Ophthalmol Vis Sci. 2012; 53:2328-2336. [PubMed: 22427553]

161. Cho YK, Zhang X, Uehara H, et al. Vascular Endothelial Growth Factor Receptor 1 morpholino increases graft survival in a murine penetrating keratoplasty model. Invest Ophthalmol Vis Sci. 2012; 53:8458-8471. [PubMed: 23150613]

162. Jun AS, Larkin DF. Prospects for gene therapy in corneal disease. Eye (Lond). 2003; 17:906-911. [PubMed: 14631395]

163. Comer RM, King WJ, Ardjomand N, et al. Effect of administration of CTLA4-Ig as protein or cDNA on corneal allograft survival. Invest Ophthalmol Vis Sci. 2002; 43:1095-1103. [PubMed: 11923251]

164. Gong N, Pleyer U, Yang J, et al. Influence of local and systemic CTLA4Ig gene transfer on corneal allograft survival. J Gene Med. 2006; 8:459-167. [PubMed: 16475216]

165. Konig Merediz SA, Zhang EP, Wittig B, et al. Ballistic transfer of minimalistic immunologically defined expression constructs for IL4 and CTLA4 into the corneal epithelium in mice after orthotopic corneal allograft transplantation. Graefes Arch Clin Exp Ophthalmol. 2000; 238:701707. [PubMed: 11011692]

166. Klebe S, Coster DJ, Sykes PJ, et al. Prolongation of sheep corneal allograft survival by transfer of the gene encoding ovine IL-12-p40 but not IL-4 to donor corneal endothelium. J Immunol. 2005; 175:2219-2226. [PubMed: 16081789]

167. Rayner SA, Larkin DF, George AJ. TNF receptor secretion after ex vivo adenoviral gene transfer to cornea and effect on in vivo graft survival. Invest Ophthalmol Vis Sci. 2001; 42:1568-1573. [PubMed: 11381062] 
168. Yang JW, Ham DS, Kim HW, et al. Expression of Stat3 and indoleamine 2, 3-dioxygenase in cornea keratocytes as factor of ocular immune privilege. Graefes Arch Clin Exp Ophthalmol. 2012; 250:25-31. [PubMed: 22072376]

169. Ryu YH, Kim JC. Expression of indoleamine 2,3-dioxy-genase in human corneal cells as a local immunosuppressive factor. Invest Ophthalmol Vis Sci. 2007; 48:4148-4152. [PubMed: 17724200]

170. Munn DH, Shafizadeh E, Attwood JT, et al. Inhibition of T cell proliferation by macrophage tryptophan catabolism. J Exp Med. 1999; 189:1363-1372. [PubMed: 10224276]

171. Beutelspacher SC, Pillai R, Watson MP, et al. Function of indoleamine 2,3-dioxygenase in corneal allograft rejection and prolongation of allograft survival by over-expression. Eur $\mathrm{J}$ Immunol. 2006; 36:690-700. [PubMed: 16482510]

172. Wang X, Wang W, Xu J, et al. Pretreatment of rapamycin before allogenic corneal transplant promotes graft survival through increasing CD4(+)CD25(+)Foxp3(+) regulatory T cells. Exp Clin Transplant. 2013; 11:56-62. [PubMed: 22769982]

173. Shin HJ, Baker J, Leveson-Gower DB, et al. Rapamycin and IL-2 reduce lethal acute graftversus-host disease associated with increased expansion of donor type CD4 + CD25 + Foxp3+ regulatory T cells. Blood. 2011; 118:2342-2350. [PubMed: 21734238]

174. Yuan XB, Yuan YB, Jiang W, et al. Preparation of rapamycin-loaded chitosan/PLA nanoparticles for immunosuppression in corneal transplantation. Int J Pharm. 2008; 349:241-248. [PubMed: 17919859]

175. Beauregard C, Huq SO, Barabino S, et al. Keratocyte apoptosis and failure of corneal allografts. Transplantation. 2006; 81:1577-1582. [PubMed: 16770247]

176. Armitage WJ, Dick AD, Bourne WM. Predicting endothelial cell loss and long-term corneal graft survival. Invest Ophthalmol Vis Sci. 2003; 44:3326-3331. [PubMed: 12882777]

177. Claerhout I, Beele H, Kestelyn P. Graft failure: I. Endothelial cell loss. Int Ophthalmol. 2008; 28:165-173. [PubMed: 17508129]

178. Salvesen GS, Dixit VM. Caspases: intracellular signaling by proteolysis. Cell. 1997; 91:443-446. [PubMed: 9390553]

179. Klausner EA, Peer D, Chapman RL, et al. Corneal gene therapy. J Control Release. 2007; 124:107-133. [PubMed: 17707107]

180. Shiraishi A, Converse RL, Liu CY, et al. Identification of the cornea-specific keratin 12 promoter by in vivo particle-mediated gene transfer. Invest Ophthalmol Vis Sci. 1998; 39:2554-2561. [PubMed: 9856765]

181. Tong YC, Chang SF, Liu CY, et al. Eye drop delivery of nano-polymeric micelle formulated genes with cornea-specific promoters. J Gene Med. 2007; 9:956-966. [PubMed: 17724775]

182. Bainbridge JW, Tan MH, Ali RR. Gene therapy progress and prospects: the eye. Gene Ther. 2006; 13:1191-1197. [PubMed: 16838031]

183. Williams KA, Coster DJ. Gene therapy for diseases of the cornea: a review. Clin Experiment Ophthalmol. 2010; 38:93-103. [PubMed: 19958372]

184. Parker DG, Brereton HM, Klebe S, et al. A steroid-inducible promoter for the cornea. $\mathrm{Br} \mathbf{J}$ Ophthalmol. 2009; 93:1255-1259. [PubMed: 19556216]

185. Uehara H, Cho Y, Simonis J, et al. Dual suppression of hemangiogenesis and lymphangiogenesis by splice-shifting morpholinos targeting vascular endothelial growth factor receptor 2 (KDR). Faseb J. 2013; 27:76-85. [PubMed: 22997228]

186. Owen LA, Uehara H, Cahoon J, et al. Morpholino-mediated increase in soluble Flt-1 expression results in decreased ocular and tumor neovascularization. PLoS One. 2012; 7:e33576. [PubMed: 22438952]

187. Cho YK, Uehara H, Young JR, et al. Vascular endothelial growth factor receptor 1 morpholino decreases angiogenesis in a murine corneal suture model. Invest Ophthalmol Vis Sci. 2012; 53:685-692. [PubMed: 22199251]

188. Simonelli F, Maguire AM, Testa F, et al. Gene therapy for Leber's congenital amaurosis is safe and effective through 1.5 years after vector administration. Mol Ther. 2010; 18:643-650.

[PubMed: 19953081] 
189. Bennett J, Ashtari M, Wellman J, et al. AAV2 gene therapy readministration in three adults with congenital blindness. Sci Transl Med. 2012; 4 120ra115.

190. Maguire AM, High KA, Auricchio A, et al. Age-dependent effects of RPE65 gene therapy for Leber's congenital amaurosis: a phase 1 dose-escalation trial. Lancet. 2009; 374:1597-1605. [PubMed: 19854499]

191. Vandenberghe LH, Bell P, Maguire AM, et al. AAV9 targets cone photoreceptors in the nonhuman primate retina. PLoS One. 2013; 8:e53463. [PubMed: 23382846]

192. Vandenberghe LH, Bell P, Maguire AM, et al. Dosage thresholds for AAV2 and AAV8 photoreceptor gene therapy in monkey. Sci Transl Med. 2011; 3 88ra54. 


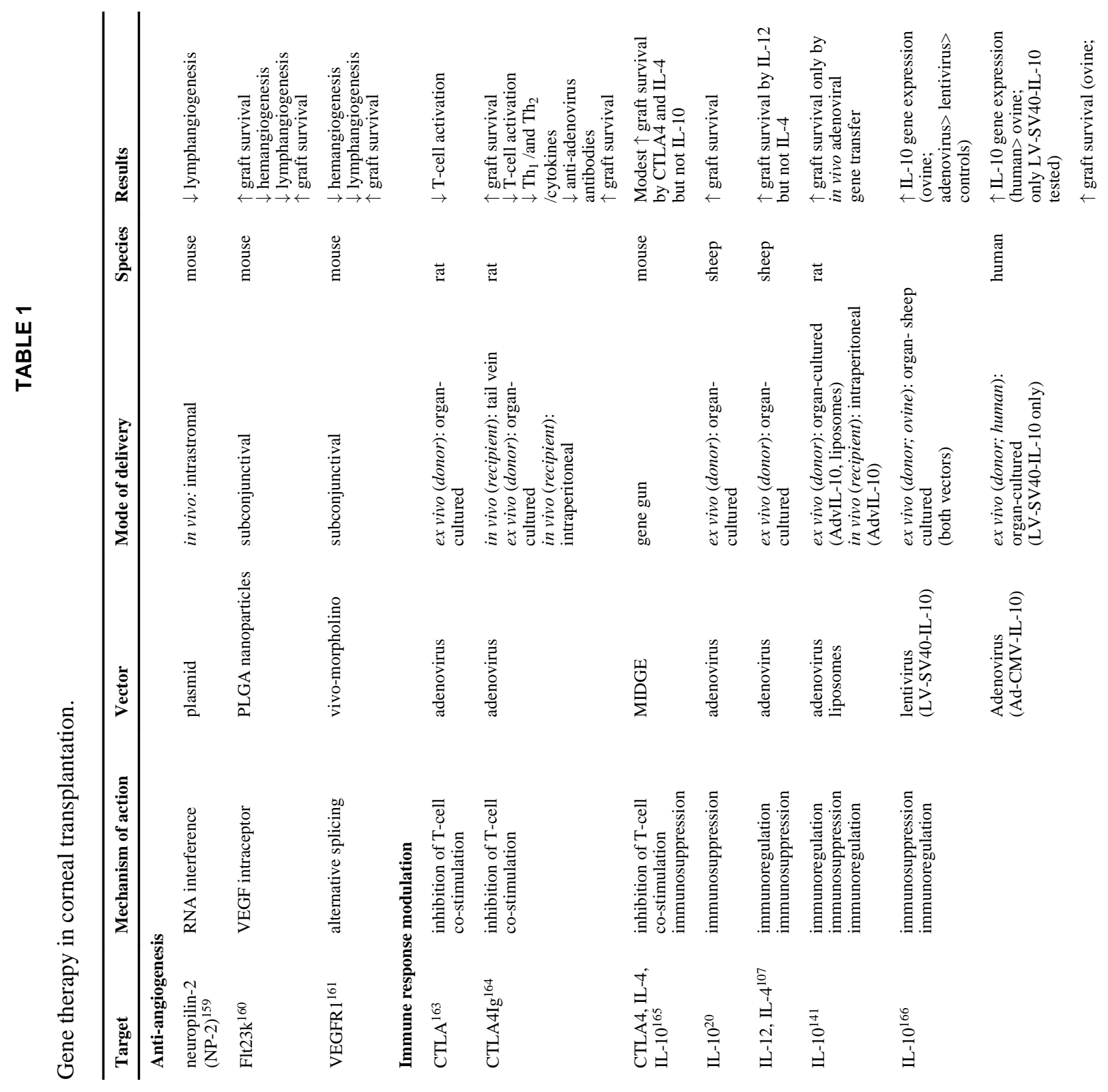




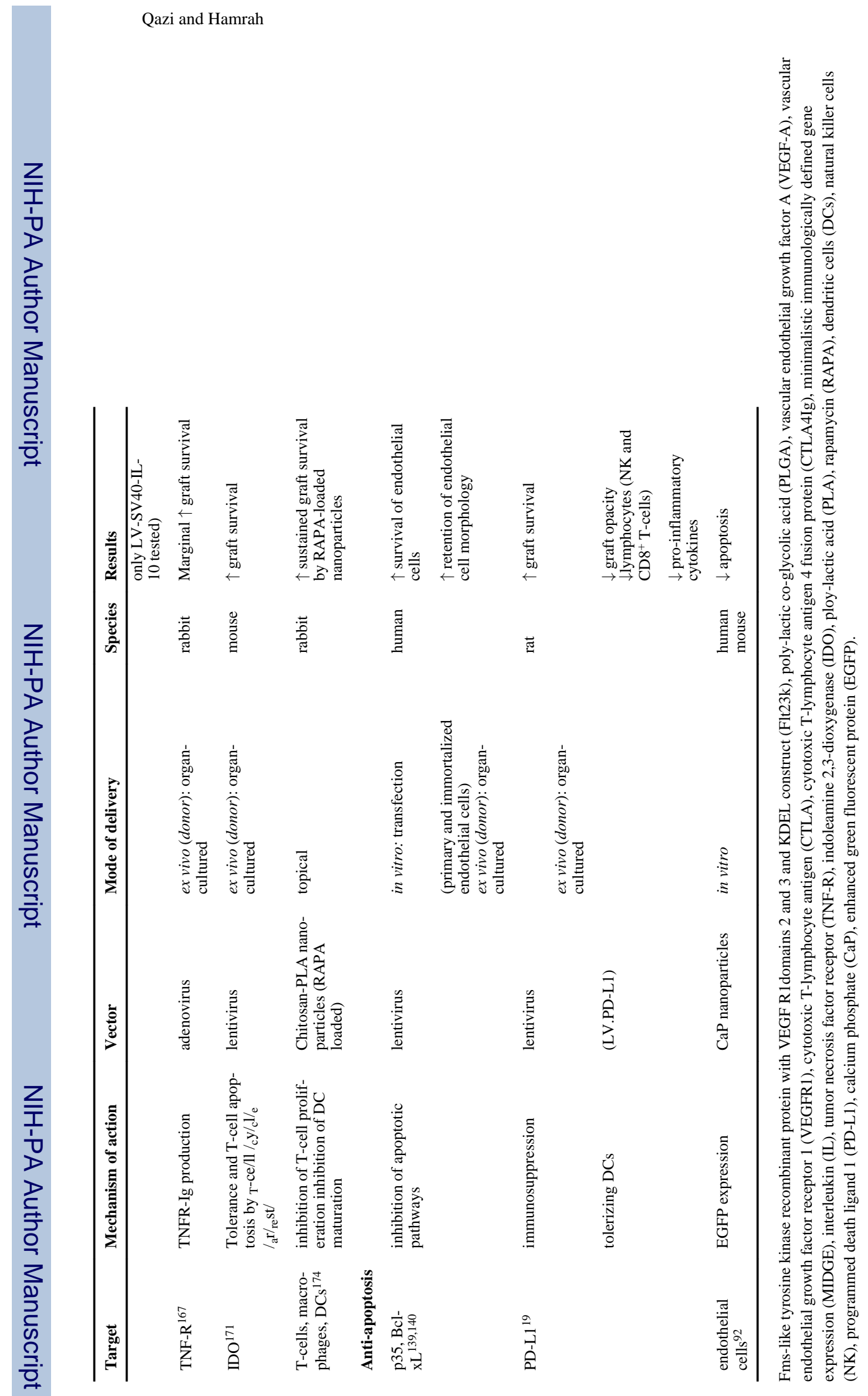

Semin Ophthalmol. Author manuscript; available in PMC 2014 September 01. 